\title{
New therapies for chronic obstructive pulmonary disease
}

\author{
Peter J Barnes
}

Chronic obstructive pulmonary disease (COPD) is common, affecting $6 \%$ of men and $4 \%$ of women over 45 years in the UK, and there is evidence that it is increasing throughout the world. It is responsible for $9 \%$ of certified sickness absence from work and imposes a large financial burden on the health service. COPD has an increasing worldwide prevalence and now ranks fifth in terms of global burden of disease. ${ }^{1}$ Treatment is often unsatisfactory and there are no currently available drug treatments that influence its progressive course. There is a widespread therapeutic nihilism, so that many patients with COPD are undertreated while others are treated as if they have asthma and this is often inappropriate. It is also important to remember that $5-10 \%$ of patients with COPD have never smoked and therefore there are other causal mechanisms apart form cigarette smoking.

In contrast to the enormous increase in our understanding of the pathophysiology of asthma, relatively little attention has been paid to COPD. The chronic airflow obstruction is due to a combination of airway disease which particularly affects small airways, and loss of lung elasticity due to enzymatic destruction of the lung parenchyma. It is likely that the latter predominates in most patients and, while this may be irreversible, it is likely to be preventable with suitable therapy.

There have been some recent advances in the therapy of COPD with improvement in bronchodilator therapy which is the mainstay of management. However, there is a need for the development of new therapies that prevent the progressive airflow obstruction in this condition.

\section{New bronchodilators}

Bronchodilators play an important role in the long term control of symptoms, but they do not alter the progression of COPD. ${ }^{2}$ The major advances have been in the development of long acting bronchodilators.

\section{NEW ANTICHOLINERGICS}

Anticholinergics are the bronchodilators of choice in the management of COPD and appear to be more effective than $\beta_{2}$ agonists. ${ }^{3}$ There have been important advances in muscarinic receptor pharmacology with the recognition of several subtypes of muscarinic receptors in airways which appear to serve different physiological functions. ${ }^{4}$ This has suggested that more selective muscarinic antagonists may have advantages over the existing non-selective drugs such as ipratropium bromide and oxitropium bromide. $M_{1}$ receptors appear to be localised to parasympathetic ganglia and blockade of these receptors results in reduced reflex bronchoconstriction. The bronchoconstrictor action of acetylcholine in human airways is mediated entirely via $M_{3}$ receptors. By contrast, $M_{2}$ receptors located at cholinergic nerve terminals inhibit the release of acetylcholine, thus acting as autoreceptors. ${ }^{5}$ Non-selective anticholinergics block $M_{1}$ and $\mathrm{M}_{3}$ receptors, leading to bronchodilatation, as a result of relieving intrinsic cholinergic tone and inhibition of cholinergic reflex bronchoconstriction. However, by blocking prejunctional $\mathrm{M}_{2}$ receptors this leads to an increase in acetylcholine release which may work against the post-junctional blockade of $\mathrm{M}_{3}$ receptors, making these antagonists less efficient. It has been difficult to develop $M_{3}$ selective antagonists, but darifenacin (UK-88 525) is reported to be $\mathrm{M}_{3}$ selective and is in clinical development. ${ }^{6}$ An $\mathrm{M}_{1} / \mathrm{M}_{3}$ selective antagonist, rispenzipine, has also been developed that does not increase acetylcholine release, ${ }^{5}$ but no clinical studies have been reported. Another $M_{1} /$ $\mathrm{M}_{3}$ antagonist, revatropate (UK-112 166), is in clinical development as a bronchodilator for COPD. ${ }^{6}$ The most promising drug is tiotropium bromide ( $\mathrm{Ba}$ 679) which has the unique property of kinetic selectivity, with rapid dissociation from $M_{2}$ receptors and slow dissociation from $M_{1}$ and $M_{3}$ receptors. ${ }^{78}$ Whether selective muscarinic antagonists will have advantages over existing non-selective drugs remains to be seen, however.

The most important property of tiotropium bromide is its very long duration of action. It has a high affinity and dissociates very slowly from muscarinic receptors in human lung ${ }^{9}$ and produces long term blockade of muscarinic receptors in human airway smooth muscle. ${ }^{10}$ This is reflected by the prolonged blockade of cholinergic neural constriction in human and guinea pig airways in vitro, with an effect lasting over eight hours in comparison with a duration of only one hour with ipratropium bromide. However, its effects on acetylcholine release are short lived and are similar to those seen with atropine and ipratropium bromide, thus confirming functional selectivity for $\mathrm{M}_{3}$ rather than $\mathrm{M}_{2}$ receptors. In clinical studies inhaled tiotropium bromide provides long term bronchodilatation and protection against cholinergic challenge in asthmatic subjects with effects lasting for more than three days. ${ }^{11}$ In studies of patients with COPD tiotropium bromide gives prolonged bronchodilatation lasting over 24 hours. ${ }^{1213}$ This suggests that tiotropium brom- 


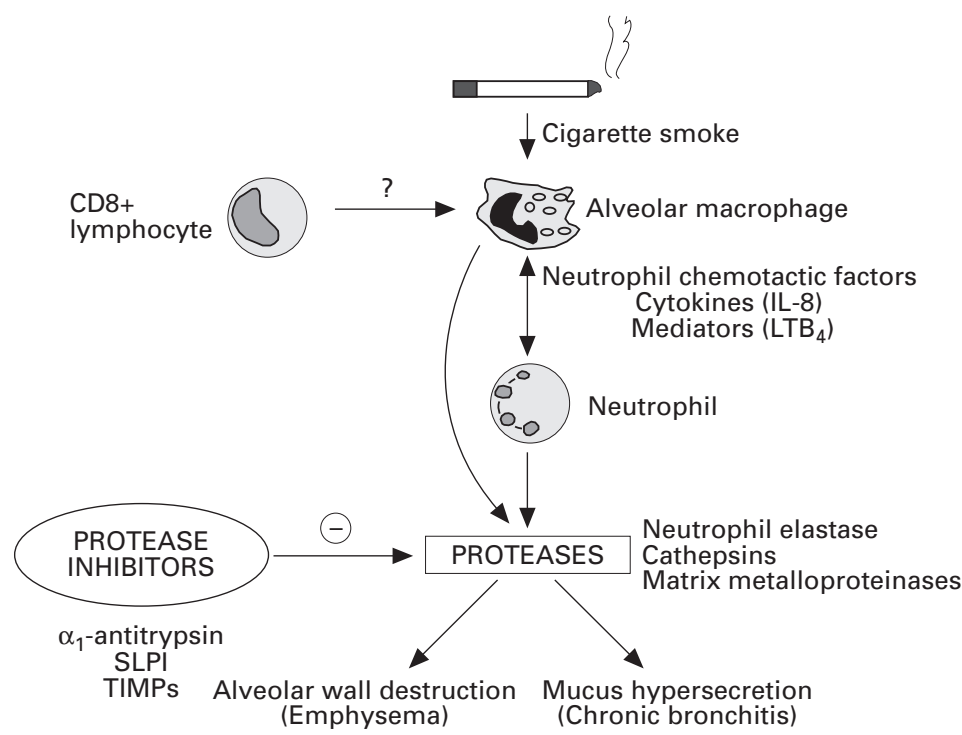

Figure 1 Inflammatory mechanisms in COPD.

ide will be suitable for once daily dosing. In phase III studies tiotropium bromide, given as a dry powder once daily, is well tolerated with no reported side effects and improves lung function in patients with COPD.${ }^{14}$ It is likely that this drug will become the bronchodilator of choice for long term management of COPD, with the advantage of improved compliance with once daily dosing.

LONG ACTING $\beta_{2}$ AGONISTS

Recent studies have shown that the long acting inhaled $\beta_{2}$ agonists salmeterol and formoterol are beneficial in patients with COPD, resulting in improved lung function and symptom control. ${ }^{15-17}$ These treatments may be a useful addition to long acting anticholinergics. In one comparative study salmeterol given twice daily was significantly better in improving lung function and symptoms than ipratropium bromide given four times daily. ${ }^{18}$

\section{Smoking cessation}

Quitting smoking is the only strategy that has so far been shown to reduce the rate of decline in lung function in patients with COPD. ${ }^{2}$ Less than one third of patients are able to give up smoking, even with support. Nicotine replacement therapy may help some patients and transdermal patches and inhaled nicotine may be the most effective delivery systems, ${ }^{19}$ but continued administration of the addictive principle of cigarettes is an unpromising approach to smoking cessation and nicotine itself theoretically may have adverse cardiovascular effects. Another approach is to develop nicotine receptor antagonists. Behavioural intervention may be helpful in some patients. ${ }^{20}$ Pharmacological methods to reduce addictive behaviour have not so far been found to be effective and a controlled trial of the anxiolytic buspirone showed no benefit. ${ }^{21}$ The novel antidepressant bupropion (Zyban), which enhances central noradrenergic activity, is reported to increase smoking cessation markedly. ${ }^{22}$ In a recent study in which bupropion was given for seven weeks smoking cessation was $44 \%$ in the treatment group compared with $19 \%$ in the placebo group. ${ }^{23}$

\section{Anti-inflammatory treatments}

COPD is characterised by inflammation of the airways. Bronchoalveolar lavage in patients with COPD shows increased numbers of neutrophils. ${ }^{24}$ Bronchial biopsy specimens have demonstrated an infiltration with mononuclear cells, CD $4+$ and, particularly, CD8 + T lymphocytes rather than neutrophils, suggesting that neutrophils may transit rapidly from the circulation into the airway lumen. ${ }^{25-28}$ Surprisingly, eosinophils may also be seen in stable COPD and increase to an even greater extent in exacerbations. ${ }^{2930}$ Biopsy specimens of exsmokers show a similar inflammatory process which suggests that, once established, inflammation may persist in the airway. ${ }^{31}$ Induced sputum in patients with COPD shows a predominance of neutrophils, even in ex-smokers, in sharp contrast to the increased levels of eosinophils seen in patients with asthma. ${ }^{32}$ There is an increased concentration of TNF$\alpha$ in the sputum ${ }^{32}$ and this is consistent with the finding of increased TNF- $\alpha$-like immunoreactivity in the airways of patients with COPD, particularly in exacerbations, and indicates that this cytokine may play a part in the inflammatory process. ${ }^{2730}$ The role of neutrophils in the lumen of COPD airways is not yet established, but it is likely that the release of enzymes such as neutrophil elastase and matrix metalloproteinases (MMP) may contribute to the pathophysiology of the disease (fig 1).

The mechanisms of the neutrophilic inflammation in COPD are not yet certain but it is likely that neutrophil chemotactic factors are released into the airways from activated macrophages and possibly from epithelial cells and CD8 + T lymphocytes. Macrophages may play an important role in driving the inflammatory process in COPD and may release neutrophil chemotactic factors as well as proteolytic enzymes. Macrophage numbers are increased by $5-10$-fold in the bronchoalveolar lavage fluid of patients with COPD and are concentrated in the centriacinar zones where emphysema is most marked. Furthermore, the number of macrophages and $\mathrm{T}$ lymphocytes, but not the number of neutrophils, in the alveolar wall is correlated with the amount of parenchymal destruction. ${ }^{33}$ Macrophages may be responsible for the continued proteolytic activity in the lungs of patients with emphysema. IL-8 is selectively chemoattractant to neutrophils and is present in high concentrations in induced sputum of patients with COPD, whereas its concentrations in those with asthma are not significantly increased. ${ }^{32}$ Furthermore, there is a significant correlation between the concentration of IL- 8 and the extent of sputum neutrophilia which indicates that there may be a causal association. IL- 8 
Table 1 Inhibitors of neutrophilic inflammation

\begin{tabular}{ll}
\hline Therapeutic class & Drugs \\
\hline LTB $_{4}$ antagonists & LY 293111, SC-53228, CP-105 696, SB 201 146 \\
Interleukin 8 inhibitors & IL-8 synthesis inhibitors, CXC receptor antagonists \\
NF-kB inhibitors & Anti-TNF $\alpha$ antibodies (cA2), soluble receptors \\
TNF inhibitors & Anti-CD11/CD18, anti-ICAM-1, E-selectin inhibitors \\
Adhesion molecule inhibitors & SB 207499, CP 80633, CDP-840 \\
Phosphodiesterase 4 inhibitors & Misoprostil, butaprost \\
$\begin{array}{l}\text { Prostaglandin E analogues } \\
\text { Colchicine }\end{array}$ & Erythromycin, clarithromycin, roxithromycin \\
Macrolide antibiotics & $N$-acetyl cysteine, stable glutathione analogues, nitrones \\
Antioxidants &
\end{tabular}

may be secreted by macrophages, neutrophils, and by airway epithelial cells. ${ }^{34}$ TNF- $\alpha$, which is also increased in the airways and in induced sputum of patients with COPD, ${ }^{273032}$ may initiate the activation of the transcription factor nuclear factor $-\kappa \mathrm{B}(\mathrm{NF}-\kappa \mathrm{B})$ which switches on the transcription of the IL-8 gene. ${ }^{35}$ Leukotriene $\mathrm{B}_{4}\left(\mathrm{LTB}_{4}\right)$ is also a potent chemotactic agent for neutrophils in the airways ${ }^{36}$ and is increased in the sputum of patients with COPD $^{37}$ and alveolar macrophages from patients with $\alpha_{1}$-antitrypsin deficiency secrete greater amounts of $\mathrm{LTB}_{4} \cdot{ }^{38}$ Several approaches have been adopted to inhibit neutrophilic inflammation (table 1).

\section{CORTICOSTEROIDS}

Because there is continued neutrophilic inflammation in COPD it was thought that inhaled corticosteroids might prevent the progression of the diseases. However, there is little evidence that inhaled corticosteroids are beneficial in COPD, ${ }^{39}$ although there may be a few patients $(\sim 10 \%)$ who have some response to steroids and these patients should probably be regarded as having concomitant asthma. In a small study there was no significant effect on lung function of inhaled budesonide with or without oral prednisolone in terms of lung function or decline in lung function. ${ }^{40} \mathrm{~A}$ recent large study (EUROSCOP) in patients with mild COPD showed no overall effect of inhaled steroids (budesonide $400 \mu \mathrm{g}$ twice daily) on the annual rate of decline in lung function, although some subgroups appeared to benefit. ${ }^{41}$ Neither inhaled nor oral steroids have any significant effect on neutrophil counts, granule proteins, or inflammatory cytokines in induced sputum, ${ }^{42}{ }^{43}$ which is consistent with a lack of effect of corticosteroids on disease progression. However, there is a small effect on neutrophil chemotactic activity, presumably mediated via an effect on macrophage or epithelial cell function. This is in marked contrast to their efficacy in asthma and their ability to reduce eosinophil counts in induced sputum. ${ }^{4344}$ However, corticosteroids are effective in treating acute exacerbations in COPD, presumably via some as yet undefined anti-inflammatory effect. ${ }^{45}$

CHEMOKINE INHIBITORS

Several chemokines are involved in neutrophil chemotaxis. ${ }^{46}$ These belong to the CXC family of chemokines, the most prominent member of which is IL-8 which is markedly increased in the sputum of patients with COPD. ${ }^{32}$ Blocking antibodies to IL- 8 and related chemokines inhibit certain types of neutrophilic inflammation in experimental animals but have not yet been used in clinical studies. It is unlikely that a humanised monoclonal antibody would be suitable for long term therapy in patients with COPD. IL-8 works through a common receptor on neutrophils shared by other members of the CXC family (CXR1) and an additional unique receptor (CXR2). These chemokine receptors have the typical 7-transmembrane spanning structure common to G-protein couples receptors. It may be possible to discover a non-peptidic inhibitor of these receptors by high throughput drug screening, but whether such drugs would be safe in long term dosing would require careful assessment. Another approach is to inhibit IL-8 synthesis. High concentrations of corticosteroids inhibit IL-8 gene transcription in airway epithelial cells, ${ }^{47}$ yet neither inhaled nor oral steroids reduce IL- 8 levels in the sputum of patients with COPD, suggesting that it is relatively resistant to steroid inhibition in vivo.

Chemokines such as IL- 8 are induced by the transcription factor $\mathrm{NF}-\kappa \mathrm{B}$ and there are several approaches to developing inhibitors for $\mathrm{NF}-\kappa \mathrm{B} \cdot{ }^{48} \mathrm{TNF}-\alpha$ levels are raised in the sputum of patients with COPD and this cytokines induces IL-8 in airway cells. ${ }^{34}$ Humanised TNF antibodies have now been developed for clinical use and have been found to be effective in other chronic inflammatory diseases such as rheumatoid arthritis and Crohn's disease.$^{49}$ Soluble TNF receptors that bind up released TNF have also been developed and are in clinical trials. This approach might be effective in the treatment of COPD.

\section{LEUKOTRIENE $\mathrm{B}_{4}\left(\mathrm{LTB}_{4}\right)$ INHIBITORS}

$\mathrm{LTB}_{4}$ is a potent chemoattractant of neutrophils and its concentrations are increased in the sputum of patients with COPD, ${ }^{37}$ probably being derived from alveolar macrophages. ${ }^{38}$ Several $\mathrm{LTB}_{4}$ receptor antagonists have now been developed and have been studied in clinical trials of asthma and inflammatory bowel disease, but not yet of COPD. A potent $\mathrm{LTB}_{4}$ antagonist (LY 293 111) is ineffective against allergen challenge in asthmatic patients, although interestingly it inhibits neutrophil recruitment into the airways during the late response, indicating its capacity to inhibit neutrophil chemotaxis in the airways. ${ }^{50}$ Several other potent $\mathrm{LTB}_{4}$ antagonists are now in development - for example, SC-53228, CP105696 , and SB $201146 . \mathrm{LTB}_{4}$ is synthesised by the enzyme 5 -lipoxygenase ( 5 -LO) of which there are now several potent inhibitors. 5-LO inhibitors such as zileuton are now available in some countries for the treatment of asthma, since they also inhibit the synthesis of cysteinyl leukotrienes, but it is not certain whether they are effective in COPD.

\section{ADHESION MOLECULE INHIBITORS}

Neutrophil recruitment into the lungs and respiratory tract is dependent on adhesion 
molecules expressed on neutrophils and endothelial cells in the pulmonary and bronchial circulations. Neutrophil adhesion in response to chemotactic factors is characterised by expression of the $\beta_{2}$ integrins CD11a/CD18 (LFA-1) and CD11b/CD18 (Mac-1) on the surface of the neutrophil and their interaction with their counter receptors, including intercellular adhesion molecule-1 (ICAM-1), on endothelial cells. ${ }^{51}$ E-selectin on endothelial cells also interacts with sialyl-Lewis on neutrophils. Bronchial biopsy specimens of patients with COPD have shown increased expression of E-selectin on vessels and ICAM-1 on epithelial cells. ${ }^{52}$ Drugs that interfere with these adhesion molecules should therefore inhibit neutrophil inflammation in COPD. Monoclonal antibodies to CD18, ICAM-1, and Eselectin inhibit neutrophil accumulation in animal models of lung inflammation. However, there are concerns about this therapeutic approach for a chronic disease as an impaired neutrophilic response may increase the susceptibility to infections. Indeed, a congenital deficiency of $\beta_{2}$ integrins results in leucocyte adhesion deficiency syndrome characterised by repeated septicaemia.

\section{PHOSPHODIESTERASE INHIBITORS}

Inhibition of phosphodiesterases (PDE) increases the cyclic AMP content of neutrophils, resulting in reduced chemotaxis, activation, degranulation, and adherence. ${ }^{53-55}$ The predominant isoenzyme is PDE4 and several PDE4 inhibitors are now in clinical development for asthma. ${ }^{56}$ It is not yet certain whether these drugs will be useful and many of the first generation PDE4 inhibitors have been limited by side effects such as nausea. In second generation PDE4 inhibitors such as SB 207499 this may be less of a problem. Theophylline is a weak and non-selective PDE inhibitor and has inhibitory effects on neutrophil function in vitro. ${ }^{53}$ Aminophylline has an inhibitory effect on neutrophil chemotaxis in vitro. ${ }^{57} \mathrm{~A}$ recent study suggests that theophylline treatment in patients with COPD reduces neutrophil counts in induced sputum. ${ }^{58}$ Pentoxyphylline is another non-selective PDE inhibitor in clinical use that inhibits experimental neutrophil migration into the lungs, but it has not been evaluated in COPD. PDE4 inhibitors may also be effective because they not only have direct effects on neutrophil functions, but by inhibiting the release of chemotactic factors from alveolar macrophages. Again, PDE4 is the predominant subtype of PDE in human alveolar macrophages. ${ }^{5960}$

Table 2 Antiproteases for COPD therapy

\begin{tabular}{ll}
\hline Therapeutic class & Drugs \\
\hline Neutrophil elastase inhibitors & ICI 200 355, ONO-5046 \\
$\begin{array}{l}\text { Cathepsin inhibitors } \\
\text { Matrix metalloproteinase inhibitors } \\
\alpha_{1} \text {-Antitrypsin }\end{array}$ & $\begin{array}{l}\text { Suramin } \\
\text { Batimastat, marimastat, selective MMP inhibitors } \\
\text { Elafin }\end{array}$ \\
$\begin{array}{ll}\text { Purified, human recombinant, gene transfer } \\
\text { Secretory leukoprotease inhibitor }\end{array}$ & Human recombinant \\
\hline
\end{tabular}

OTHER NEUTROPHIL INHIBITORS

Prostaglandin (PG) $E_{2}$ is a potent inhibitor of the oxidative burst in neutrophils and its effects are mediated via $\mathrm{EP}_{2}$ receptors. ${ }^{6}{ }^{1}$ Selective $\mathrm{EP}_{2}$ agonists such as misoprostil and butaprost may therefore be effective in suppressing neutrophil activation but have not been studied in COPD.

Colchicine potently inhibits neutrophil activation, enzyme release, and chemotaxis by disrupting cytoskeletal microtubule structure. A controlled trial of colchicine in COPD showed some reduction in neutrophil elastase activity ${ }^{62}$ and in an observational study smokers who were treated with colchicine had a lower annual decline in lung function than smokers not treated with colchicine. ${ }^{63}$

Macrolide antibiotics such as erythromycin, clarithromycin, and roxithromycin have inhibitory effects on neutrophil function that are independent of their antibiotic actions. ${ }^{64}$ This may be through some ill defined membrane stabilising property and may account for the efficacy of macrolides in the treatment of diffuse panbronchilitis, with a reduction in neutrophilic inflammation and elastase activity in bronchoalveolar lavage fluid. ${ }^{65}$

SURFACTANT

Surfactant is important for preventing airway closure, but also has immunomodulatory effects and is important for normal mucociliary clearance. Cigarette smoking reduces surfactant production and this may contribute to the detrimental effects of cigarette smoking on airway function. ${ }^{66}$ This suggests that exogenous surfactant therapy might be beneficial in COPD, but the high cost of currently available preparations has made clinical studies difficult.

There are reports that ambroxol increases surfactant secretion in lungs of experimental animals ${ }^{67}$ but this has not been demonstrated in patients with COPD. ${ }^{68}$

\section{Antiproteases}

There is considerable evidence that, in patients with COPD, there is an imbalance between proteases that digest elastin and those that protect against this. ${ }^{69}$ This suggests that either inhibiting these proteolytic enzymes or increasing antiproteases may be beneficial and theoretically should prevent the progression of airflow obstruction in COPD (table 2). Considerable progress has been made in identifying the enzymes involved in elastolytic activity in emphysema and in characterising the endogenous antiproteases that counteract this activity.

NEUTROPHIL ELASTASE INHIBITORS

Neutrophil elastase, a neutral serine protease, is a major constituent of lung elastolytic activity and also potently stimulates mucus secretion. ${ }^{70}$ In addition, neutrophil elastase induces IL-8 release from epithelial cells and therefore may perpetuate the inflammatory state. ${ }^{71}$ This has led to a search for neutrophil elastase inhibitors. ${ }^{72}$ Peptide inhibitors of neutrophil elas- 
tase such as ICI 200355 , and non-peptide inhibitors such as ONO-5046, have been developed which have a high potency. ${ }^{7374}$ These drugs inhibit neutrophil elastase-induced lung injury in experimental animals, whether given by inhalation or systemically, ${ }^{73}$ and inhibit neutrophil elastase-induced mucus secretion in vitro. ${ }^{75}$ There are few clinical studies with neutrophil elastase in patients with COPD. One study with oral MR889 administered for four weeks showed no overall effect on plasma levels of elastin-derived peptides or urinary levels of desmosine (markers of elastolytic activity), but these may not be sensitive markers. ${ }^{76}$ Although neutrophil elastase is likely to be the major mechanism mediating elastolysis in patients with $\alpha_{1}$-antitrypsin $\left(\alpha_{1}-\mathrm{AT}\right)$ deficiency, it may well not be the major elastolytic enzyme in smoking related COPD and it is important to consider other enzymes as targets for inhibition.

\section{CATHEPSIN INHIBITORS}

Neutrophil elastase is not the only proteolytic enzyme secreted by neutrophils. Cathepsin G and proteinase 3 have elastolytic activity and may need to be inhibited together with neutrophil elastase. Cathepsins (cathepsins B, L and $S$ ) are also released from macrophages. Recently it has been found that suramin, a hexasulphonated naphthylurea which has been used as an anti-tumour drug, is a potent inhibitor of cathepsin $\mathrm{G}$, proteinase 3, and neutrophil elastase. ${ }^{77}$

\section{MATRIX METALLOPROTEINASE INHIBITORS}

Matrix metalloproteinases (MMPs) are a group of over 20 closely related endopeptidases that are capable of degrading all of the components of the extracellular matrix of lung parenchyma, including elastin, collagen, proteoglycans, laminin and fibronectin. They are produced by neutrophils, but also by alveolar macrophages. ${ }^{78}$ Airway epithelial cells may also release MMPs. ${ }^{79}$ Recently, increased levels of collagenase (MMP-1) and gelatinase B (MMP9) have been reported in bronchoalveolar lavage fluid of patients with emphysema. ${ }^{80}$ Bronchoalveolar macrophages from patients with emphysema express more gelatinase $B$ and collagenase than cells from control subjects, suggesting that these cells rather than neutrophils may be the major source of these MMPs. ${ }^{81}$ Alveolar macrophages also express a unique MMP, macrophage metalloelastase (MMP12), ${ }^{82}$ which plays a key role in murine models of emphysema ${ }^{83}$ MMP-12 knock-out mice do not develop emphysema and do not show the expected increases in lung macrophages after long term exposure to cigarette smoke as occurs in normal animals. ${ }^{84}$ Tissue inhibitors of metalloproteinases (TIMP) are endogenous inhibitors of these potent enzymes and three different TIMPs have now been characterised.

There are several approaches to inhibiting MMPs. ${ }^{85}$ One approach is to enhance the secretion of TIMPs and another is to inhibit the induction of MMPs in COPD. MMPs may show increased expression with cigarette smok- ing through induction in response to inflammatory cytokines, oxidants, and other enzymes such as neutrophil elastase. It may be possible to prevent this induction with specific transcription inhibitors. Another approach is to develop specific inhibitors. Tetracyclines and hydroxamates such as batimastat (BB-94) and the orally active marimastat (BB-2516) are non-selective MMP inhibitors. ${ }^{86}$ Broad spectrum MMP inhibitors also inhibit an enzyme, TNF convertase, that inhibits the release of active TNF- $\alpha$ which may be an additional beneficial property. Side effects of such drugs may be a problem. More selective inhibitors of individual MMPs such as gelatinase $B$ and macrophage metalloelastase are now in development and are likely to be better tolerated in chronic therapy. However, it is still not clear whether there is one predominant MMP in COPD or whether a broad spectrum inhibitor would be preferable.

\section{$\alpha_{1}$-ANTITRYPSIN}

The association of $\alpha_{1}$-AT deficiency with emphysema suggested that this endogenous inhibitor of neutrophil elastase may be of therapeutic benefit in COPD. Cigarette smoking may inactivate $\alpha_{1}$-AT, resulting in unopposed activity of neutrophil elastase and cathepsins. Extraction of $\alpha_{1}$-AT from human plasma is very expensive and extracted $\alpha_{1}$-AT is only available in a few countries (USA and Germany). This treatment has to be given intravenously and has a half life of only five days. This has led to the development of inhaled formulations. ${ }^{87}$ Nebulised $\alpha_{1}$-AT reduces neutrophil elastase activity in patients with cystic fibrosis. ${ }^{88}$ However, inhaled $\alpha_{1}$-AT is inefficient and expensive and could only be indicated in patients with severe $\alpha_{1}$-AT deficiency. Recombinant $\alpha_{1}$-AT with amino acid substitutions to increase stability may result in a more stable product. Gene therapy is another possibility using an adenovirus vector or liposomes, but there have been major problems in developing efficient delivery systems. There is a particular problem with gene transfer in $\alpha_{1}$ AT deficiency in that large amounts of protein (1-2 g) need to be synthesised each day. Human $\alpha_{1}$-AT has now been available for over 10 years but even in patients with severe $\alpha_{1}$ AT deficiency and emphysema there is only a marginal effect on the rate of decline in $\mathrm{FEV}_{1}{ }^{89}$ There is no evidence that $\alpha_{1}$-AT treatment would halt the progression of COPD and emphysema in patients with normal plasma levels.

Other serum protease inhibitors (serpins) such as elafin may also be important in counteracting elastolytic activity in the lung. Elafin, an elastase-specific inhibitor, is found in bronchoalveolar lavage fluid and is synthesised by epithelial cells in response to inflammatory stimuli. ${ }^{90}$ Serpins may not be able to inhibit neutrophil elastase at the sites of elastin destruction due to the tight adherence of the inflammatory cell to connective tissue. ${ }^{91}$ Furthermore, these proteins may become inactivated by the inflammatory process and the action of oxidants so that they may not be able 
to counteract elastolytic activity in the lung adequately unless used in conjunction with other therapies. ${ }^{92}$

SECRETORY LEUKOPROTEASE INHIBITOR

Secretory leukoprotease inhibitor (SLPI) is a $12 \mathrm{kDa}$ serpin that appears to be a major inhibitor of elastase activity in the airways. It is secreted by epithelial cells ${ }^{90}$ and its secretion is increased by corticosteroids. ${ }^{93}$ In vitro recombinant human SLPI is more effective at inhibiting neutrophil mediated proteolysis than $\alpha_{1}$-AT. ${ }^{94}$ Recombinant human SLPI given by aerosolisation increases SLPI and antineutrophil elastase activity in epithelial lining fluid for over 12 hours, indicating potential therapeutic usefulness. ${ }^{95}$

\section{Mediator antagonists}

ANTIOXIDANTS

There is considerable evidence that oxidative stress is increased in patients with COPD and that reactive oxygen species contribute to its pathophysiology. ${ }^{96}$ Oxidants are present in cigarette smoke and are produced endogenously by activated inflammatory cells including neutrophils and alveolar macrophages. Increased production of endogenous oxidants is demonstrated by the increased levels of hydrogen peroxide $\left(\mathrm{H}_{2} \mathrm{O}_{2}\right)$ in expired condensates from patients with COPD, particularly during exacerbations. ${ }^{97}$ There is also increased production of nitric oxide in exhaled air. ${ }^{98}$ Oxidants may contribute to the pathophysiology of COPD in several ways, including damage of serpins, potentiation of elastase activity, and increased mucus secretion. In addition, oxidants activate the transcription factor $N F-\kappa B$ which orchestrates the transcription of many inflammatory genes including IL-8 and inducible NO synthase. ${ }^{35}$

This suggests that antioxidants may be of use in the treatment of COPD. $N$-acetyl cysteine (NAC) provides cysteine for enhanced production of glutathione (GSH) and has antioxidant effects in vitro and in vivo. NAC inhibits endotoxin-induced neutrophilic inflammation in rat lungs through inhibition of $\mathrm{NF}-\kappa \mathrm{B}$. In clinical studies NAC reduces the number of exacerbations of $\mathrm{COPD}^{99}$ and in an uncontrolled study appeared to reduce the rate of decline in $\mathrm{FEV}_{1}$ over a two year period. ${ }^{100}$ Although epidemiological studies have linked COPD to poor intake of dietary antioxidants such as vitamins $\mathrm{C}$ and $\mathrm{E}$, there have been no controlled trials of these vitamins in the treatment of COPD.

It is likely that more effective antioxidants will be developed for clinical use in the future. Spin trap antioxidants such as $\alpha$-phenyl-N-tertbutyl nitrone are much more potent and inhibit the formation of intracellular reactive oxygen species by forming stable compounds. ${ }^{101}$ These compounds are effective in animal models of oxidative stress. ${ }^{102}$ They are now entering clinical trials and their use in COPD should be considered.
PROSTANOID INHIBITORS

Oxidative stress may result in the non-enzymatic formation of prostanoid mediators (isoprostanes) directly from arachidonic acid without the involvement of cyclo-oxygenase. ${ }^{103}$ There is increased formation of isoprostanes in cigarette smokers ${ }^{104}$ and one isoprostane (8epi-prostaglandin $\mathrm{F}_{2 \alpha}$ ) is a potent constrictor of human airways, acting via stimulation of thromboxane (TP) receptors. ${ }^{105}$ This suggests that thromboxane receptor antagonists such as seratrodast and Bay u3405 might be beneficial in COPD.

The role of prostaglandins in COPD is unknown. Inhalation of the cyclo-oxygenase inhibitor indomethacin is reported to reduce mucus hypersecretion in patients with COPD. ${ }^{106}$ In patients with bronchiectasis indomethacin has an inhibitory effect on chemotaxis of peripheral neutrophils but no effect on neutrophils in sputum. ${ }^{107}$ It is likely that such an effect may be mediated via inducible cyclooxygenase (COX-2), and selective COX-2 inhibitors such as meloxicam and NS-398, which may have a reduced tendency to cause gastrointestinal problems, are now in clinical development.

\section{Pulmonary vasodilators}

Pulmonary hypertension due to chronic hypoxia is a late complication of COPD in some patients and leads to cor pulmonale. There are no vasodilators that are selective for the pulmonary rather than the systemic circulation, so that vasodilator therapy with current agents is potentially hazardous due to systemic hypotension. ${ }^{108}$ The development of selective pulmonary vasodilators depends on selective delivery via the inhaled route or the development of drugs that inhibit the mechanism of hypoxic constriction and structural remodelling that occur in secondary pulmonary hypertension. While prevention of structural remodelling is desirable, it is not certain whether relief of hypoxic vasoconstriction may worsen the chronic hypoxia in COPD by increased shunting.

\section{PROSTACYCLIN ANALOGUES}

Beraprost, an orally active form of prostacyclin, is more stable and has been reported to have a beneficial effect in pulmonary hypertension. ${ }^{109}$ Nebulised prostacyclin and its more stable analogue, iloprost, are also reported to be effective and the inhaled route appears to reduce the systemic side effects seen with intravenous prostacyclin. ${ }^{110}$

NITRIC OXIDE DONORS

Inhaled nitric oxide (NO) has been used for some time as a selective pulmonary vasodilator due to its short duration of action and inactivation in the systemic circulation ${ }^{111}$ but it is difficult to use over a prolonged period. Several NO donor compounds have been developed but suffer from the disadvantage that they cause systemic vasodilatation. 


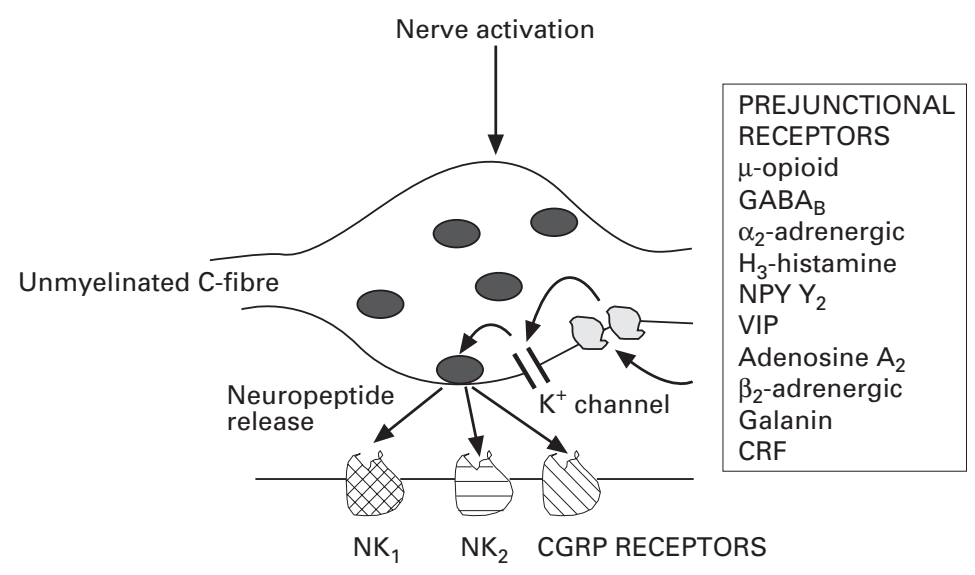

Figure 2 Modulation of neurogenic mucus secretion via post-junctional receptors or prejunctional receptor blockade which may open a common potassium $\left(K^{+}\right)$channel.

ENDOTHELIN ANTAGONISTS

Endothelin has potent constrictor effects on airway and pulmonary vascular smooth muscle and may play a role in COPD as its synthesis is increased by hypoxia. ${ }^{112}$ Endothelin-1 (ET-1) is strongly expressed in the pulmonary vascular endothelium of patients with pulmonary hypertension secondary to chronic hypoxia ${ }^{113}$ and urinary ET-1 excretion is increased in patients with COPD. ${ }^{114}$ ET-1, acting mainly via $\mathrm{ET}_{\mathrm{A}}$ receptors, induces fibrosis and hyperplasia of pulmonary vascular smooth muscle, implying a role in the pulmonary hypertension secondary to COPD. This suggests that ET-1 antagonists may prevent the development of pulmonary hypertension. Potent orally active non-peptide endothelin antagonists such as bosentan and SB 217242 have now been developed. The non-selective antagonist bosentan and the $\mathrm{ET}_{\mathrm{A}}$ receptor antagonist BQ123 inhibit the development of pulmonary hypertension in rats after chronic hypoxia. ${ }^{115116}$ Potent non-peptide selective orally active $\mathrm{ET}_{\mathrm{A}}$ antagonists such as PD 156707 have also now been developed.

ANGIOTENSIN ANTAGONISTS

Angiotensin II is a potent pulmonary and airway constrictor acting via angiotensin (AT) receptors. Non-peptide inhibitors of $\mathrm{AT}_{1}$ receptors such as losartan have now been developed. Losartan inhibits hypoxic pulmonary vasoconstriction and the remodelling that occurs in the pulmonary circulation after chronic hypoxia. ${ }^{117}$ Losartan reduces pulmonary artery pressure in patients with COPD ${ }^{118}$ and therefore may be useful in preventing the progression of pulmonary hypertension and cor pulmonale in patients with severe COPD. $\mathrm{An}_{\mathrm{AT}}$ receptor antagonist PD 123319 does not appear to affect the pulmonary response to hypoxia. ${ }^{117}$

\section{Mucoregulators}

Increased secretion of mucus is found in all patients who smoke heavily, irrespective of airflow obstruction. However, recent epidemiological data suggest that mucus hypersecretion is significantly associated with a more rapid decline in $\mathrm{FEV}_{1}$ and increased hospitalisation of patients with COPD. ${ }^{119}$ This suggests that it may be important to develop drugs that inhibit the hypersecretion of mucus, although it will be important to find drugs that do not suppress the normal mucus secretion and impair mucociliary clearance. There are several types of mucoregulatory drugs in development.

\section{TACHYKININ ANTAGONISTS}

Tachykinins are potent stimulants of mucus secretion from submucosal glands and goblet cells in human and animal airways and act via $\mathrm{NK}_{1}$ receptors. ${ }^{120121}$ In animal studies cigarette smoke induces airway mucus secretion via release of tachykinins from sensory nerves though a local axon reflex mechanism. ${ }^{122} \mathrm{NK}_{1}$ antagonists markedly inhibit neurogenic mucus secretion $^{123}$ and may therefore be useful as mucoregulators in cigarette smoke induced chronic bronchitis. Several potent non-peptide $\mathrm{NK}_{1}$ receptor antagonists such as CP-99 994 and SR 140333 are now in clinical development and, while it is unlikely that they will be useful in asthma, they might have a role as regulators of mucus hypersecretion in COPD. A clinical trial of a non-selective peptide tachykinin antagonist FK-224 appeared to show some clinical benefit in patients with COPD, with a decrease in mucus production and coughing. ${ }^{124}$

SENSORY NEUROPEPTIDE RELEASE INHIBITORS Another approach to blocking tachykinin-mediated effects is to inhibit the release of tachykinins from sensory nerve endings via activation of pre-junctional receptors (fig 2). ${ }^{125}$ Of these receptors, $\mu$-opioid receptors are most effective and the $\mu$-opioid agonist morphine potently inhibits cigarette smoke-induced mucus secretion in animal airways. ${ }^{126}$ In human airways in vitro morphine inhibits mucus secretion activated via stimulation of sensory nerves. ${ }^{127}$ While morphine itself may not be useful as a therapeutic agent because of addiction, peripherally acting opioid agonists that do not cross the blood brain barrier, such as BW443, might be of use. ${ }^{128}$

Many pre-junctional receptors appear to operate via the opening of a common potassium (K) channel, suggesting that $\mathrm{K}$ channel openers may be useful in blocking mucus secretion. Openers of ATP-dependent $\mathrm{K}$ channels such as cromakalim do, indeed, have an inhibitory effect on cigarette smoke-induced mucus secretion in animals. ${ }^{129}$

\section{MEDIATOR AND ENZYME INHIBITORS}

Many mediators stimulate mucus secretion from submucosal glands and/or goblet cells and may therefore contribute to increased mucus secretion in COPD. It is unlikely, however, that any mediator antagonists such as antileukotrienes would have a major effect on mucus secretion. As noted above, neutrophil elastase and other proteases are potent stim- 
ulants of submucosal gland and goblet cell secretion, suggesting that protease inhibitors may have inhibitory effects on mucus secretion, as well as inhibiting lung destruction. As noted above, inhalation of the cyclo-oxygenase inhibitor indomethacin is reported to reduce mucus hypersecretion in patients with $\mathrm{COPD}^{106}$ but long term trials of COX inhibitors have not been undertaken.

MUC GENE SUPPRESSORS

Several MUC genes that code for mucin synthesis have now been cloned. ${ }^{130}$ MUC2 and MUC5AC appear to be particularly important in airway mucus and MUC5AC may be upregulated by inflammatory cytokines and inhibited by glucocorticoids. ${ }^{131}$ It is possible that drugs may be developed that inhibit the abnormally increased expression of MUC genes (predominantly MUC5AC in COPD) while preserving baseline secretion of MUC2. Such drugs, other than steroids, have not yet been developed.

MUCOLYTIC AGENTS

Several drugs were developed to reduce viscosity of mucus, thus aiding clearance from the respiratory tract. These drugs include cysteine derivatives such as $\mathrm{N}$-acetyl cysteine, methyl cysteine, and carbocisteine which were effective in reducing mucus viscosity in vitro, but there is little convincing evidence that they increase mucus clearance in patients with COPD. DNAse also reduces sputum viscosity, particularly when sputum is infected, as DNA is a major determinant of sputum viscosity. Although nebulised recombinant human DNAse (dornase alfa) appears to improve the rheological properties of mucus in patients with cystic fibrosis, ${ }^{132}$ this has not been reported in COPD. It is possible that more effective mucolytic agents will be developed in the future.

MACROLIDE ANTIBIOTICS

Erythromycin inhibits mucin secretion from human airways in vitro and appears to be interactive with dexamethasone. ${ }^{133}$ Erythromycin and clarithromycin also reduce endotoxin-induced mucus discharge from goblet cells in guinea pig trachea. ${ }^{134}$ This property does not appear to be related to its antibiotic activity and is consistent with other studies demonstrating an inhibitory action of erythromycin on cell secretion. There is a clinical case report of the efficacy of erythromycin in treating mucus hypersecretion, ${ }^{135}$ and clarithromycin has been reported to reduce nasal secretion of mucus in patients with rhinitis. ${ }^{136}$ This suggests that the molecular mechanisms involved in these effects need to be defined and that studies in COPD may be indicated.

\section{Drugs affecting remodelling}

Since a major mechanism of airway obstruction in COPD is caused by loss of elastic recoil resulting from proteolytic destruction of lung parenchyma, it seems unlikely that this could be reversible by drug therapy, although it might be possible to reduce the rate of progression by preventing the inflammatory and enzymatic disease process. Retinoic acid increases the number of alveoli in developing rats and, remarkably, reverses the histological and physiological changes induced by elastase treatment. ${ }^{137}$ Retinoic acid activates retinoic acid receptors which act as transcription factors to regulate the expression of many genes. The molecular mechanisms involved and whether this can be extrapolated to humans is not yet known. Several retinoic acid receptor subtype agonists have now been developed that may have a greater selectivity for this effect.

\section{Delivery systems}

Bronchodilators are currently given as inhalers, either metered dose inhalers or dry powder inhalers, that have been optimised to deliver drugs to the respiratory tract. However, in emphysema the inflammatory process takes place in the lung parenchyma. This implies that a drug to be delivered by inhalation should have a lower mass median diameter so that there is preferential deposition in the lung periphery. It may be more appropriate to give the drug parenterally as it will need to reach the lung parenchyma via the pulmonary circulation, but parenteral administration may increase the risk of systemic side effects.

\section{Future directions}

There is a pressing need for the development of new drugs for the treatment of COPD. While preventing and quitting smoking is the obvious preferred approach, this has proved to be very difficult in the majority of patients. In addition, it is likely that the inflammatory process initiated by cigarette smoking may continue even when smoking has ceased. Furthermore, approximately $10 \%$ of patients with COPD are non-smokers. COPD may be caused by other environmental factors (pollutants, passive smoking, other inhaled toxins) or by development changes in the lungs.

It is important to identify the factors that determine why only $15 \%$ of smokers develop COPD. So far this is little understood, although it is likely that genetic factors are important. ${ }^{138}$ The only clearly established genetic risk factor for COPD is the $\mathrm{ZZ}$ allele of the $\alpha_{1}$-antitrypsin gene, although heterozygotes may be at slightly increased risk. There are also weak associations with $\alpha_{1}$-antichymotrypsin, $\alpha_{2}$-macroglobulin, and vitamin $\mathrm{D}$ binding protein. A polymorphism in the gene for the enzyme microsomal epoxide hydrolase responsible for the metabolism of reactive epoxide intermediates which may be generated in tobacco smoke has recently been found to be associated with a 4-5 fold increased risk of COPD and emphysema. ${ }^{139}$ It is likely that many other genetic polymorphisms will be discovered that will confer risk on smokers for the development of COPD and emphysema, so that it will even- 
tually be possible to identify at risk patients and focus more effective therapies on them before lung function becomes too impaired.

Several new drugs are now in development that may be useful in COPD. These include $\mathrm{LTB}_{4}$ antagonists and 5-lipoxygenase inhibitors, PDE4 inhibitors, new antioxidants and neutrophil elastase and MMP inhibitors. It will be difficult to demonstrate the efficacy of such treatments as determination of the effect of any drug on the rate of decline in lung function will require large studies over at least two years. There is an urgent need to develop surrogate markers such as analysis of sputum parameters (cells, mediators, enzymes) that may predict the clinical usefulness of such drugs. More research on the basic cellular and molecular mechanisms of COPD and emphysema are urgently needed to aid the logical development of new therapies for this common and important disease for which no effective preventative treatments currently exist.

1 Murray CJL, Lopez A. Evidence based health policy: lessons from the global burden of disease. Science 1996; 274:740-3.

2 Anthonisen NR, Connett JE, Kiley JP, et al. Effects of smoking intervention and the use of an inhaled anticholinergic bronchodilator on the rate of decline of $\mathrm{FEV}_{1}$. fAMA 1994;272:1497-505.

3 Rennard SI, Serby CW, Ghafouri M, Johnson PA, Friedman $M$. Extended therapy with ipratropium is associated with improved lung function in patients with COPD. A with improved lung function in patients with COPD. A retrospective analysis of

4 Barnes PJ. Muscarinic receptor subtyes in airways. Life Sci 1993;52:521-8

5 Patel HJ, Barnes PJ, Takahashi T, Tadjkarimi S, Yacoub MH, Belvisi MG. Characterization of prejunctional muscarinic autoreceptors in human and guinea-pig trachea in vitro. Am f Respir Crit Care Med 1995;152:872-8.

6 Alabaster VA. Discovery and development of selective $M_{3}$ antagonists for clinical use. Life Sci 1997;60:1053-60.

7 Disse B, Reichal R, Speck G, Travnecker W, Rominger KL, Hammer R. Ba679BR, a novel anticholinergic bronchodilator: preclinical and clinical aspects. Life Sci 1993;52:537-44.

8 Barnes PJ, Belvisi MG, Mak JCW, Haddad E, O'Connor B. Tiotropium bromide (Ba $679 \mathrm{BR}$ ), a novel long-acting muscarinic antagonist for the treatment of obstructive airways disease. Life Sci 1995;56:853-9.

9 Haddad E, Mak JCW, Barnes PJ. Characterization of $[3 \mathrm{H}] \mathrm{Ba} 679$, a slow-dissociating muscarinic receptor antagonist in human lung: radioligand binding and autoradiographic mapping. Mol Pharmacol 1994;45:899-907.

10 Takahashi T, Belvisi MG, Patel $\mathrm{H}$, et al. Effect of $\mathrm{Ba}$ $679 \mathrm{BR}$, a novel long-acting anticholinergic agent, on cholinergic neurotransmission in guinea-pig and human airways. Am f Respir Crit Care Med 1994;150:1640-5.

11 O'Connor BJ, Towse LJ, Barnes PJ. Prolonged effect of tiotropium bromide on methacholine-induced bronchoconstriction in asthma. Am $\mathcal{F}$ Respir Crit Care Med 1996;154:876-80

12 Maesen FPV, Smeets JJ, Costongs MAL, Wald FDM, Cornelissen PJG. BA $679 \mathrm{Br}$, a new long-acting antimuscarinic bronchodilator; a pilot dose-escalation study. Eur Respir f 1993;6:10316.

13 Maesen FPV, Smeets JJ, Sledsens TJM, Wald FDM, Cornelissen JPG. Tiotropium bromide, a new long-acting antimuscarinic bronchodilator: a pharmacodynamic study in patients with chronic obstructive pulmonary study in patients with chronic obstructive pulm
disease (COPD). Eur Respir 7 1995;8:1506-13.

14 Littner M, Auerbach D, Campbell S, et al. The bronchodilator effects of tiotropium bromide in stable COPD. Am J Respir Crit Care Med 1997;155:A282.

15 Ulrik CS. Efficacy of inhaled salmeterol in the management of smokers with chronic obstructive pulmonary disease: a single centre, randomised, double blind, placebo controlled crossover study. Thorax 1995;50:750-4.

16 Boyd G, Morice AH, Pounsford JC, Siebert M, Peslis N, Crawford C. An evaluation of salmeterol in the treatment of chronic obstructive pulmonary disease (COPD). Eur Respir f 1997;10:815-21.

17 Cazzola M, Matera MG, Santangelo G, Vinciguerra A, Rossi F, D'Amato G. Salmeterol and formoterol in partially reversible severe chronic obstructive pulmonary disease: a dose-response study. Respir Med 1995;89:357-62.

18 Anderson W, Wisniewski M, Barbee R, Rickard K. A comparison of Serevent and ipratropium on pulmonary function in COPD patients reversible to ipratropium. $\mathrm{Am}$ f Respir Crit Care Med 1997;155:A277.
19 Silagy C, Mint D, Fowler G, Ludge M. Meta-analysis on efficacy of nicotine replacement therapies in smoking cessation. Lancet 1994;343:139-42.

20 Foulds J. Strategies for smoking cessation. Br Med Bull 1996;52:157-73.

21 Schneider NG, Olmstead RE, Steinberg C, Sloan K, Daims RM, Brown HV. Efficacy of buspirone in smoking ces1996;60:568-75.

22 Lief HI. Bupropion treatment of depression to assist smoking cessation. Am f Psychiatry 1996;153:442.

23 Hurt RD, Sachs DPL, Glover ED, et al. A comparison of sustained-release bupropion and placebo for smoking cessation. N Engl f Med 1997;337:1195-202.

24 Thompson PB, Daughton D, Robbins GA, Ghafouki MA, Oehlerking $M$, Rennard SI. Intramural airway inflammation in chronic bronchitis. Characterization and correlation with clinical parameters. Am Rev Respir Dis 1989;140:1527-37.

25 Saetta M, Di Stefano A, Maestrelli P, et al. Activated Tlymphocytes and macrophages in bronchial mucosa of subjects with chronic bronchitis. Am Rev Respir Dis 1993 147:301-6.

26 Bosken CM, Hards J, Gatter X, Hogg JC. Characterization of the inflammatory reaction on the peripheral airways of cigarette smokers using immunocyctochemistry. Am Rev Respir Dis 1992;145:911-7.

27 Mueller R, Chanez P, Campbell AM, Bousquet J, Heusse C, Bullock GR. Different cytokine patterns in bronchial C, Bullock GR. Different cytokine patterns in bronchial
biopsies in asthma and chronic bronchitis. Respir Med 1996;90:79-85.

28 O'Shaughnessy TC, Ansari TW, Barnes NC, Jeffery PK Inflammation in bronchial biopsies of subjects with chronic bronchitis: inverse relationship of CD8 + T lymphocytes with $\mathrm{FEV}_{1}$. Am $\mathcal{F}$ Respir Crit Care Med 1997; 155:852-7.

29 Lacoste JY, Bousquet J, Chanez P. Eosinophilic and neutrophilic inflammation in asthma, chronic bronchitis and chronic obstructive pulmonary disease. $\mathcal{F}$ Allergy Clin Immunol 1993;92:537-48.

30 Saetta M, Distefano A, Maestrelli P, et al. Airway eosinophilia in chronic bronchitis during exacerbations. Am inophilia in chronic bronchitis during exace

31 Turato G, Di Stefano A, Maestrelli P, et al. Effect of smoking cessation on airway inflammation in chronic bronchitis. Am J Respir Crit Care Med 1995;152:1262-7.

32 Keatings VM, Collins PD, Scott DM, Barnes PJ. Differences in interleukin- 8 and tumor necrosis factor- in induced sputum from patients with chronic obstructive pulmonary disease or asthma. Am 7 Respir Crit Care Med 1996;153:530-4.

33 Finkelstein R, Fraser RS, Ghezzo H, Cosio MG. Alveola inflammation and its relation to emphysema in smokers. Am f Respir Crit Care Med 1995;152:1666-72.

$34 \mathrm{Kwon}$ OJ, Au BT, Collins PD, et al. Tumor necrosis factor-induced interleukin 8 expression in cultured human factor-induced interleukin 8 expression in cultured

35 Barnes PJ, Karin M. Nuclear factorkB: a pivotal transcription factor in chronic inflammatory diseases. $N$ Eng f Med 1997;336:1066-71

36 Martin TR, Pistorese BP, Chi EY, Goodman RB, Matthay MA. Effects of leukotriene $B_{4}$ in the human lung. recruitment of neutrophils into the alveolar spaces without a change in protein permeability. F Clin Invest 1989;84: 1609-19.

37 Zakrzewski JT, Barnes NC, Costello JF, Piper PJ. Lipid mediators in cystic fibrosis and chronic obstructive pulmediators in cystic fibrosis and chronic obstructive pul-

38 Hubbard RC, Fells G, Gadek J, Pacholok S, Humes J, Crystal RG. Neutrophil accumulation in the lung in $\alpha_{1}$ antitrypsin deficiency. Spontaneous release of leukotrien $\mathrm{B}_{4}$ by alveolar macrophages. F Clin Invest 1991;88:891-7.

39 McEvoy CE, Niewoehner DE. Adverse effects of corticosteroid therapy for COPD. A critical review. Chest 1997; 111:732-43.

40 Renkema TE, Schouten JP, Koeter GH, Postma DS Effects of long-term treatment with corticosteroids in COPD. Chest 1996;109:1156-62.

41 Pauwels RA, Löfdahl C, Pride NB, Postma DS, Laitinen LA, Ohlsson SV. European Respiratory Society study on chronic obstructive pulmonary disease (EUROSCOP): hypothesis and design. Eur Respir f 1992;5:1254-61.

42 Llewellyn Jones CG, Harris TA, Stockley RA. Effect of Llewellyn Jones CG, Harris TA, Stockley RA. Effect of
fluticasone propionate on sputum of patients with chronic bronchitis and emphysema. Am f Respir Crit Care Med 1996;153:616-21.

43 Keatings VM, Jatakanon A, Worsdell YM, Barnes PJ. Effects of inhaled and oral glucocorticoids on in flammatory indices in asthma and COPD. Am $\mathcal{F}$ Respir Crit Care Med 1997;155:542-8.

44 Claman DM, Boushey HA, Liu J, Wong H, Fahy JV. Analysis of induced sputum to examine the effects of prednisone on airway inflammation in asthmatic subjects. prednisone on airway inflammation in 1994 .

45 Thompson WH, Nielson CP, Carvalho P, Charan NB, Crowley JJ. Controlled trial of oral prednisone in outpatients with acute COPD exacerbation. Am f Respir Crit patients with acute COPD exac
Care Med 1996;154:407-12.

46 Adams DH, Lloyd AR. Chemokines: leucocyte recruitment and activation cytokines. Lancet 1997;349:490-5.

47 Kwon OJ, Au BT, Collins PD, et al. Inhibition of interleukin-8 expression in human cultured airway epithelia cells. Immunology 1994;81:389-94. 
48 Barnes PJ, Adcock IM. NF-кB: a pivotal role in asthma and a new target for therapy. Trends Pharmacol Sci 1997; 18:46-50.

49 Elliott MJ, Maini RN, Feldmann M, et al. Randomised double-blind comparison of diuretic monoclonal antibody to tumour necrosis factor $\alpha$ (cA2) versus placebo in rheumatoid arthritis. Lancet 1994;344:1105-10.

50 Evans DJ, Barnes PJ, Coulby LJ, et al. The effect of a leukotriene $\mathrm{B}_{4}$ antagonist LY293111 on allergen-induced responses in asthma. Thorax 1996;51:1178-84.

51 Frenette PS, Wagner DD. Adhesion molecules - Part II: Blood vessels and blood cells. N Engl f Med 1996;335: 43-5.

52 Di Stefano A, Maestrelli P, Roggeri A, et al. Upregulation of adhesion molecules in the bronchial mucosa of subjects with chronic obstructive bronchitis. Am $\mathcal{F}$ Respir Crit Care Med 1994;149:803-10.

53 Nielson CP, Vestal RE, Sturm RJ, Heasli PR. Effect of selective phosphodiesterase inhibitors on the polymorphonuclear leukocyte respiratory burst. $\mathcal{F}$ Allergy Clin Immunol 1990;86:801-8.

54 Schudt C, Winder S, Forderkunz S, Hatzelmann A, Ullrich $\mathrm{V}$. Influence of selective phosphodiesterase inhibitors on human neutrophil functions and levels of cAMP and Cai. Naunyn Schmiedeberg's Arch Pharmacol 1991;344:682-90.

55 Bloemen PG, van den Tweel MC, Henricks PA, et al. Increased cAMP levels in stimulated neutrophils inhibit their adhesion to human bronchial epithelial cells. $A m \mathcal{F}$ Physiol 1997;272:L580-7.

56 Muller T, Engels P, Fozard J. Subtypes of the type 4 cAMP phosdphodiesterase: structure, regulation and selective phosdphodiesterase: structure, regulation and

57 Llewellyn Jones CG, Stockley RA. The effects of $\beta_{2}$ agonists and methylxanthines on neutrophil function in vitro. Eur Respir F 1994;7:1460-6.

58 Culpitt S, Maziak W, Loukides S, Keller A, Barnes PJ. Effect of theophylline on induced sputum inflammatory indices in COPD patients. Am $\mathcal{F}$ Respir Crit Care Med 1998;157 (in press)

59 Dent G, Giembycz MA, Rabe KF, Wolf B, Barnes PJ, Magnussen $\mathrm{H}$. Theophylline suppresses human alveolar macrophage respiratory burst through phosphodiesteras
inhibition. Am $\mathcal{F}$ Respir Cell Mol Biol 1994;10:565-72.

60 Tenor H, Hatzelmann A, Kupferschmidt R, et al. Cyclic nucleotide phosphodiesterase isoenzyme activities in
human alveolar macrophages. Clin Exp Allergy 1995;25: 625-33.

61 Talpain E, Armstrong RA, Coleman RA, Vardey CJ. Characterization of the PGE receptor subtype mediating inhibition of superoxide production in human neutrophils. Br F Pharmacol 1995;114:1459-65.

62 Cohen AB, Girard W, Mclarty J, et al. A controlled trial of colchicine to reduce the elastase load in the lungs of cigarette smokers with chronic obstructive pulmonary disease. Am Rev Respir Dis 1990;142:63-72.

63 Sanchez CW, Lavietes MH, Pokomey ES. Effect of colchicine on pulmonary function. Am $\mathcal{f}$ Respir Crit Care Med 1997;155:A282.

64 Anderson R, Theron AJ, Feldman C. Membrane-stabilizing, anti-inflammatory interactions of macrolides with human neutrophils. Inflammation 1996;20:693-705.

65 Ichikawa Y, Ninomiya $\mathrm{H}$, Koga $\mathrm{H}$, et al. Erythromycin reduces neutrophils and neutrophil-derived elastolyticlike activity in the lower respiratory tract of bronchiolitis like activity in the lower respiratory tract of bron
patients. Am Rev Respir Dis 1992;146:196-203.

66 Hohlfeld J, Fabel H, Hamm H. The role of pulmonary surfactant in obstructive airways disease. Eur Respir $\mathcal{f}$ surfactant in ob

67 Oetomo SB, Lewis J, Ikegami M, Jobe AH. Surfactant treatments after endogenous surfactant metabolism in rabbit lungs. F Appl Physiol 1990;68:1590-6.

68 Lusuardi M, Capelli A, Salmona M, Tacconi MT, Cerutti CG, Donner CF. Intraluminal inflammation in the airways of patients with chronic bronchitis after treatment with Ambroxol. Monaldi Arch Chest Dis 1995;50:346-51.

69 Stockley RA. The role of proteninases in the pathogenesis of chronic bronchitis. Am F Respir Crit Care Med 1994; 150:S109-13.

70 Sommerhoff CP, Nadel JA, Basbaum CB, Caughey GH. Neutrophil elastase and cathepsin G stimulate secretion from cultured bovine airway gland serous cells. $\mathcal{F}$ Clin Invest 1990;85:682-9.

71 Nakamura H, Yoshimura K, McElvaney NG, Crystal RG. Neutrophil elastase in respiratory epithelial lining fluid of individuals with cystic fibrosis induces interleukin- 8 gene expression in a human bronchial epithelial cell line. $f$ Clin Invest 1992;89:1478-84.

72 Bernstein PR, Edwards PD, Williams JC. Inhibitors of human leukocyte elastase. In: Ellis GP, Luscombe DK, eds. Progress in medicinal chemistry. Amsterdam: Elsevier, 1994: 59-120.

73 Williams JC, Falcone RC, Knee C, et al. Biologic characterization of ICI 200,880 and ICI 200,355 , novel inhibitors of human neutrophil elastase. Am Rev Respir Dis 1991;144:875-83.

74 Kawabata K, Suzuki M, Sugitani M, Imaki K, Toda M, Miyamoto T. ONO-5046, a novel inhibitor of human neutrophil elastase. Biochem Biophys Res Commun 1991; 177:814-20

75 Sommerhoff CP, Krell RD, Williams JL, Gomes BC, Strimpler AM, Nadel JA. inhibition of human neutrophil elastase by ICI 200,355. Eur f Pharmacol 1991;193:153-8.

76 Luisetti M, Sturani C, Sella D, et al. MR889, a neutrophil elastase inhibitor, in patients with chronic obstructive pulmonary disease: a double-blind, randomized, placebocontrolled clinical trial. Eur Respir f 1996;9:1482-6.

77 Cadene M, Duranton J, North A, Si Tahar M, Chignard $\mathrm{M}$, Bieth JG. Inhibition of neutrophil serine proteinases by suramin. F Biol Chem 1997;272:9950-5.

78 Shapiro SD. Elastolytic metalloproteinases produced by human mononuclear phagocytes. Potential roles in destructive lung disease. Am 7 Respir Crit Care Med 1994, 150:S160-4.

79 Yao PM, Buhler JM, D'Ortho MP, et al. Expression of matrix metalloproteinase gelatinases $\mathrm{A}$ and $\mathrm{B}$ by cultured epithelial cells from human bronchial explants. F Biol
Chem 1996;271:15580-9.

80 Finlay GA, Russell KJ, McMahon KJ, et al. Elevated levels of matrix metalloproteinases in bronchoalveolar lavage of matrix metalloproteinases in bronchoalveolar lavage

81 Finlay GA, O'Driscoll LR, Russell KJ, et al. Matrix metalloproteinase expression and production by alveolar macrophages in emphysema. Am $\mathcal{F}$ Respir Crit Care Med 1997; 156:240-7.

82 Shapiro SG, Kobayashi DK, Ley TJ. Cloning and characterization of a unique elastolytic metalloproteinase produced by human alveolar macrophages. F Biol Chem 1993 268:23824-9.

83 Shipley JM, Wesselschmidt RL, Kobayashi DK, Ley TJ, Shapiro SD. Metalloelastase is required for macrophagemediated proteolysis and matrix inv

84 Hautamaki RD, Kobayashi DK, Senior RM, Shapiro SD. Requirement for macrophage metalloelastase for cigarette smoke-induced emphysema in mice. Science 1997;277: 2002-4.

85 Cawston TE. Metalloproteinase inhibitors and the prevention of connective tisue breakdown. Pharmacol Ther 1996;70:163-82.

86 Wojtowicz Praga SM, Dickson RB, Hawkins MJ. Matrix metalloproteinase inhibitors. Invest New Drugs 1997;15: 61-75.

87 Hubbard RC, Crystal RG. Strategies for aerosol therapy of alpha 1-antitrypsin deficiency by the aerosol route. Lung 1990;168 (Suppl):565-78

88 McElvaney DG, Hubbard RC, Birper P, et al. Aerosol $\alpha_{1}$ antitrypsin treatment for cystic fibrosis. Lancet 1991;337: 392-4

89 Seersholm N, Wencker M, Banik N, et al. Does $\alpha_{1}$-antitrypsin augmentation therapy slow the annual decline in $\mathrm{FEV}_{1}$ in patients with severe hereditary $\alpha_{1}$-antitrypsin deficiency. Eur Respir f 1997;10:2260-3.

90 Sallenave JM, Shulmann J, Crossley J, Jordana M, Gauldie J. Regulation of secretory leukocyte proteinase inhibitor (SLPI) and elastase-specific inhibitor (ESI/elafin) in human airway epithelial cells by cytokines and neutrophilic enzymes. Am f Respir Cell Mol Biol 1994;11:733-41.

philic enzymes. Am f Respir Cell Mol Biol 1994;11:733-41
91 Campbell EJ, Senior RM, McDonald JM, Cox DW. Proteolysis by neutrophils. Relative importance of cell-substrate contact and oxidative inactivation of proteinase inhibitors in vitro. F Clin Invest 1982;70:845-52.

92 Smith SF, Roberts NA, Guz A, Tetley TD. Compromised inhibition of human lung lavage cell elastases. FEBS Let 1996;390:187-90.

93 Abbinante-Nissen JM, Simpson LG, Leikauf GD. Corticosteroids increase secretory leukocyte protease inhibito transcript levels in airway epithelial cells. Am $\mathcal{F}$ Physio 1995;12:L601-6.

94 Llewellyn Jones CG, Lomas DA, Stockley RA. Potentia role of recombinant secretory leucoprotease inhibitor in the prevention of neutrophil mediated matrix degradation. Thorax 1994;49:567-72.

95 McElvaney NG, Doujaiji B, Moan MJ, Burnham MR Wu MC, Crystal RG. Pharmacokinetics of recombinant secretory leukoprotease inhibitor aerosolized to normals and individuals with cystic fibrosis. Am Rev Respir Dis 1993;148:1056-60.

96 Repine JE, Bast A, Lankhorst I. Oxidative stress in chronic obstructive pulmonary disease. Am 7 Respir Crit Care Med obstructive pulmon

97 Dekhuijzen PNR, Aben KHH, Dekker I, et al. Increased exhalation of hydrogen peroxide in patients with stable and unstable chronic obstructive pulmonary disease. $A m$ f Respir Crit Care Med 1996;154:813-6.

98 Maziak W, Loukides S, Culpitt S, Sullivan P, Kharitonov SA, Barnes PJ. Exhaled nitric oxide in chronic obstructive pulmonary disease. Am $\mathcal{F}$ Respir Crit Care Med 1998;157 (in press).

99 Boman G, Backer U, Larsson S, Melander B, Wahlander L. Oral acetylcysteine reduces exacerbation rate in chronic bronchitis: report of a trial organized by the Swedish Society for Pulmonary Diseases. Eur 7 Respir Dis 1983; 64:405-15.

100 Lundback B, Lindstrom M, Jonsson E, Anderson S, van Herwaarden C. Effect of $\mathrm{N}$-acetylcysteine on the decline in lung function in patients with COPD. Eur Respir 7 in lung function in pappli5):895.

101 Thomas CE, Ohlweiler DF, Carr AA, et al. Characterization of the radical trapping activity of a novel series of terization of the radical trapping activity of a novel series of

102 Miyajima T, Kotake Y. Spin trapping agent, phenyl N-tertbutyl nitrone, inhibits induction of nitric oxide synthase in endotoxin-induced shock in mice. Biochem Biophys Res Commun 1995;215:114-21.

103 Morrow JD, Roberts LJ. The isoprostanes. Current knowledge and directions for future research. Biochem Pharmacol 1996;51:1-9.

104 Morrow JD, Frei B, Longmire AW, et al. Increase in circulating products of lipid peroxidation (F2-iso- 
prostanes) in smokers. Smoking as a cause of oxidative damage. $N$ Engl f Med 1995;332:1198-203.

105 Kawikova I, Barnes PJ, Takahashi T, Tadjkarimi S, Yacoub $\mathrm{MH}$, Belvisi MG. 8-epi-prostaglandin $\mathrm{F}_{2 x}$, a novel noncyclooxygenase derived prostaglandin, is a potent constrictor of guinea-pig and human airways. Am 7 Respir Crit Care Med 1996;153:590-6.

106 Tamaoki J, Chiyotani A, Kobayashi S, Noritaka T, Kanemura $T$, Takizawa $T$. Effect of indomethacin on bronchorrhea with chronic bronchitis, diffuse panbronchiolitis or bronchiectasis. Am Rev Respir Dis 1992;145:548-52.

107 Llewellyn Jones CG, Johnson MM, et al. In vivo study of indomethacin in bronchiectasis: effect on neutrophil of indomethacin in bronchiectasis: effect on neutrophil

108 Barnes PJ, Liu S. Regulation of pulmonary vascular tone. Physiol Rev 1995;47:87-118.

109 Okano Y, Yoshioka T, Shimouchi A, Satoh T, Kunieda T. Orally active prostacyclin analogue in primary pulmonary hypertension. Lancet 1997;349:1365.

110 Olschewski H, Walmrath D, Schermuly R, Ghofrani A, Grimminger F, Seeger W. Aerosolized prostacyclin and iloprost in severe pulmonary hypertension. Ann Intern Med 1996;124:820-4.

111 Pepke Zaba J, Higenbottam TW, Dinh Xuan AT, Stone $\mathrm{D}$, Wallwork J. Inhaled nitric oxide as a cause of selective pulmonary vasodilatation in pulmonary hypertension. pulmonary vasodilatation

112 Barnes PJ. Endothelins and pulmonary diseases. $f \mathrm{Appl}$ Physiol 1994:77:1051-9.

113 Giaid A, Yanagisawa M, Langleben D, et al. Expression of endothelin-1 in the lungs of patients with pulmonary hypertension. N Engl f Med 1993:328:1732-9.

114 Sofia M, Mormile M, Faraone S, et al. Increased 24-hour endothelin-1 urinary excretion in patients with chronic obstructive pulmonary disease. Respiration 1994;61:2638.

115 Dicarlo VS, Chen SJ, Meng QC, et al. ETA-receptor antagonist prevents and reverses chronic hypoxia-induced pulmonary hypertension in rat. Am $\mathcal{F}$ Physiol 1995;269: L690-7.

116 Eddahibi S, Raffestin B, Clozel M, Levame M, Adnot S. Protection from pulmonary hypertension with an orally Protection from pulmonary hypertension with an orally f Physiol 1995;268:H828-35.

117 Morrell NW, Morris KG, Stenmark KR. Role of angiotensin-converting enzyme and angiotensin II in development of hypoxic pulmonary hypertension. $A m \mathcal{F}$ Physiol 1995;269:H1186-94.

118 Kiely DG, Cargill RI, Wheeldon NM, Coutie WJ, Lipworth BJ. Haemodynamic and endocrine effects of type 1 angiotensin II receptor blockade in patients with hypoxaemic cor pulmonale. Cardiovasc Res 1997;33:201-8.

119 Vestbo J, Prescott E, Lange P. Association of chronic mucus hypersecretion with $\mathrm{FEV}_{1}$ decline and chronic obstructive pulmonary disease morbidity. Copenhagen City Heart pulmonary disease morbidity. Copenhagen City Heart 1530-5.

120 Rogers DF, Aursudkij B, Barnes PJ. Effects of tachykinins on mucus secretion on human bronchi in vitro. Eur $\mathcal{F}$ Pharmacol 1989;174:283-6.

121 Kuo H, Rhode JAL, Tokuyama K, Barnes PJ, Rogers DF. Capsaicin and sensory neuropeptide stimulation of goblet cell secretion in guinea pig trachea. F Physiol 1990;431: $629-41$

122 Kuo H, Barnes PJ, Rogers DF. Cigarette smoke-induced airway goblet cell secretion: dose dependent differential nerve activation. Am f Physiol 1992;7:L161-7.

123 Ramnarine SI, Hirayama Y, Barnes PJ, Rogers DF. "Sensory-efferent" neural control of mucus secretion: characterization using tachykinin receptor antagonists in ferret trachea in vitro. Br f Pharmacol 1994;113:1183-90.

124 Ichinose M, Katsumata U, Kikuchi R, et al. Effect of tachykinin receptor antagonist on chronic bronchitis patients. Am Rev Respir Dis 1993;147:A318.

125 Barnes PJ, Belvisi MG, Rogers DF. Modulation of neurogenic inflammation: novel approaches to inflammatory diseases. Trends Pharmacol Sci 1990;11:185-9.

126 Kuo H-P, Rohde J, Barnes PJ, Rogers DF. Differentia effects of opioids on cigarette smoke, capsaicin and electrically-induced goblet cell secretion in guinea pig trachea. trically-induced goblet cell secretion
Br f Pharmacol 1992;105:361-6.

127 Rogers DF, Barnes PJ. Opioid inhibition of neurally mediated mucus secretion in human bronchi : implications for chronic bronchitis therapy. Lancet $1989 ; \mathrm{i}: 930-2$.

128 Posner J, Dear K, Jeal S, et al. A prelimary study of the pharmacodynamics and pharmacokinetics of a novel enkephalin analogue (Tyr-D.Arg-Gly-Phe $\left(4 \mathrm{NO}_{2}\right)$ Pro. $\left.\mathrm{NH}_{2}\right)(\mathrm{BW} 443 \mathrm{C})$ in healthy volunteers. Eur $\mathcal{F}$ Cli (1988:34:67-71.

129 Kuo H, Rohde JAL, Barnes PJ, Rogers DF. K+ channel activator inhibition of neurogenic goblet cell secretion in guinea pig trachea. Eur f Pharmacol 1992;221:385-8.

130 Gendler SJ, Spicer AP. Epithelial mucin genes. Anпu Rev Physiol 1995;57:607-34.

131 Kai H, Yoshitake K, Hisatsune A, et al. Dexamethasone suppresses mucus production and MUC-2 and MUC-
5AC gene expression by NCI-H292 cells. Am f Physiol 1996;271:L484-8.

132 Shah PL, Scott SF, Knight RA, Marriott C, Ranasinha C, Hodson ME. In vivo effects of recombinant human DNase I on sputum in patients with cystic fibrosis. Thora 1996;51:119-25.

133 Goswami SK, Kivity S, Marom Z. Erythromycin inhibits respiratory glycoconjugate secretion from human airways in vitro. Am Rev Respir Dis 1990;141:72-8.

134 Tamaoki J, Nakata J, Takeyama K, Chiyotani A, Konno K. Histamine $\mathrm{H}_{2}$ receptor-mediated airway goblet cell secretion and its modulation by histamine-degrading ensecretion and its modulation by histamine-deg

135 Marom ZM, Goswami SK. Respiratory mucus hypersecretion (bronchorrhea): a case discussion - possible mechanisms(s) and treatment. f Allergy Clin Immunol 1991;87:1050-5.

136 Rubin BK, Druce H, Ramirez OE, Palmer R. Effect of clarithromycin on nasal mucus properties in healthy subjects and in patients with purulent
Crit Care Med 1997;155:2018-23.

137 Massaro G, Massaro D. Retinoic acid treatment abrogates elastase-induced pulmonary emphysema in rats. Nature elastase-induced pulm

138 Sandiford AJ, Weir TD, Pare PD. Genetic risk factors fo chronic obstructive pulmonary disease. Eur Respir f 1997 10:1380-91

139 Smith CAD, Harrison DJ. Association between polymorphism in gene fro microsomal epoxide hydrolase and susceptibility to emphysema. Lancet 1997;350:630-3. 